\title{
An Essay on the Phenomenon of Violence and Alienation Originate in the Context of the Symbolism and Signification Process
}

\author{
S. Aydin, A. C. Çiçek, M. Ç. Artunay, and A. B. Certel
}

\begin{abstract}
Humans are social beings by nature. Their social character requires human beings to be in interaction with the environment they are surrounded by. This interaction process creates shared symbolism and a world of meaning. A human being has an active character that creates meaning. The world of meaning created by a person is the reason of communities and togetherness in a society. By ascribing meaning to symbols a person builds a common world. Mankind's effort to make sense of life causes unity but it also causes division and conflict. As the meaning people ascribe to notions changes, people and groups of people start to grow apart and alienation occurs. The increasing alienation causes the meaning attributed to symbols and concepts to differ and different forms of violence takes place. The process of alienation/ differentiation caused by the struggle to make sense of the world is the reason behind the violence committed by the members of a religion against members of a different religion as well as the violence committed by the members of the same religion against the members of a different sect of the same religion. The aim of this study is to provide an overview of the phenomenon of violence as a result of the alienation that was caused by the process of social interaction and signification.
\end{abstract}

Index Terms-Alienation, interpretation, symbolic interactionism, phenomenon of violence.

\section{INTRODUCTION}

From the first moment of life to this moment, the phenomenon of violence was always on the agenda of humankind. Violence was considered as a notion that was occasionally praised and seen as a threat to the structures of society at other times. Although the notion of violence is tried to be defined as a negative concept and be excluded from social life, in the era that we currently live in, the reality of violence has been on the agenda of every society throughout history. The notion of violence takes an important part in every moment of life and yet it is quite difficult to define. Violence has a complex content that has many types. Because of its complex content different types of violence can be seen in different areas. It is the mankind himself who created violence. The process of people trying and struggling to make sense of the world may lead to coexistence as it may also cause alienation. A human being makes sense of the world by signification of symbols and interacts with other people by the use of these symbols. The meaning attached to symbols may be the key to build a common social order, as

Manuscript received November 29, 2014; revised January 22, 2015.

The authors are with the Faculty of Economics and Administrative Sciences, Department of Political Science and Public Administration, Kafkas University, Turkey (e-mail: atilcemcicek@yahoo.com). it may lead to an order which may cause violence.

One of the most important means of symbolic interaction is the language used. Language is a common world of meaning which had been transformed into symbols. The process of interpretation through language makes people understand each other and build a common understanding of the world but it can also lead to alienation. The increasing alienation of people from other people and from one's self leads people to grow apart from each other which then lead to violence.

The process of symbolism and interpretation paves the way for legitimate grounds for violence. Violence in its essence is a tool for establishing domination over others. This tool has legitimate grounds because of the interpretation process of alienation.

In this study conducted discourse analyze by using descriptive and historical research methods as a methodology.

\section{CONCEPTUAL FRAMEWORK: ALIENATION - SyMBOLISM AND INTERPRETATION-VIOLENCE}

\section{A. Alienation}

There is not one single point of view and an agreement regarding the content and scope of the term alienation. Throughout history the concept of alienation has been used with different meanings in different fields of social studies, science, philosophy, literature, psychology and psychiatry. Alienation is a concept that had been a subject of almost all the humanities and social sciences having the meaning of a man being alone in a hostile universe all by himself. Alienation which has been an important concept for the last two centuries it was Hegel who first removed it from the service of theology and considered it as a concept of philosophy [1]. Hegel's alienation, in itself, implies its own elimination. Alienation is the other entity that is the opposite of consciousness and self consciousness, the object and the subject. Therefore, the essence of alienation that had to be overcome is the objectification of a human being by himself, separated from the geist. Alienated object is nothing but consciousness [2].

Feuerbach is another philosopher who before Karl Marx had a philosophical take on the concept of alienation. Feuerbach was against the idea of Hegel who suggested that nature is a self-alienated form of the absolute geist. Feuerbach asserted that man is not a self-alienated God but that God is a self-alienated human. According to Feuerbach's religious alienation theory, man alienates from himself and objectifies himself by creating the God. Man becomes the 
slave of the God image which he created and turned into the Supreme Being. The created one begins to dominate the creators; the created becomes the creator [1].

Karl Marx is the one who gave the concept of alienation a holistic character. Marx indicates that Hegel identifies commodification with estrangement. Marx criticizes Hegel's take on alienation because it is nothing more than different interpretations of consciousness and because it reduces alienation of a person to alienation of his consciousness [3]. On the other hand, Marx indicates that Feurbach's take on religious alienation is one from many types of alienation.

Karl Marx states that the process of alienation starts the moment a commodity is in the market for the first time and when its use value is assigned an exchange value. He says that the first sin is committed at that moment and with a "salto mortal" (death somersault) the process of alienation begins. He states that this "moment" is also like the "moment" (the curse) which determines the transition of the primal classless societies (from the matriarchal periods) to stratified patriarchal societies. After this point, he indicates that, throughout history, in all of the class societies, the human-human relations and psychic harmony of a human is disrupted and fragmented; individuals/people started reitification and objectification. [4]. In broad terms, Marx perceived alienation as an act of alienation of the worker from the product of his labour, from the act of producing, from himself, his species-essence, his humanity, and from other people [2].

Marx, in his words explains shortly as follows: "in their life, for example property, industry, religion, the estranged elements such as the unbridled freedom of movement of the individual independence of an individual that serves as seemingly her own, in reality is his slavery and non-human." [2]. From the core of one's own breaking off her at the same time taking people to slavery itself and around the bite off her own human alienation. Alienated from his own humanity is possible violence for the individual. The legitimization of violence remains in the back. It is a world of meaning in life through own their symbols shaping creates legitimate ground.

\section{B. Symbolic Interaction-Interpretation Process and the Language}

The notion of symbolic interaction and interpretation is a product of a sociological perspective called symbolic interactionism which relies heavily on the process of social act, social interaction and on signification and interpretation that arises from that process [5]. Symbolic interactors think that social order is formed as a result of the process of ascribing meaning to the things (objects, events, act, etc.) in the world we live in [5]. In other words, the community is made up of the ascribed meanings to the world they live in not from structures separate from the individual.

These symbols or icons have a critical importance related to the process of signification because they represent the things that we ascribe to these symbols. Indeed, a symbol, an object or an event does not only represent, but it also defines the specific aspects. In this regard, one of the leading symbolic interactors Blumer makes three basic propositions to indicate the meaning and source of the importance of human action, but also the role of meaning arising from the interpretation process: The first of these, people behave according to things and the meaning of things implied. Secondly, the meaning of things is formed by social interactions among people. The third one is the meaning of things changes as people encounter them and as they go through the process of interpretation [6].

Hence, according to symbolic interactionism meanings are not imminent within the objects. The meanings that represent thing/ symbols in everyday life occur in the process of interaction among the members of the community. Because the meanings are formed during social interactions they are not constant and stable. They keep changing during social consensus and interpretation processes. During this time, social order and social world forms itself every day.

Symbols that provide any kind of meaningful communication among people can both be words that stand for linguistic meanings and be objects, signs, gestures, hand and arm movements without any linguistic meanings. However, language is one of the important and powerful symbolic interactions. People build a meaningful social world by using symbols.

Language is a symbolic tool that we use to generate thoughts and describe the thoughts which we generate. Language emerges both as a requirement and a product of human activity. The relationship between language and violence and to dominate and establish authority over others through language is related to the social and psychological aspect of language. As it generates and harbours many emotions it also generates and transfers violence. The spoken language itself can be an act of violence and not remain as an object that mediates for establishing power. Both power and violence is determined and rendered by social relationships [7]. Social relations of individuals cause the world of meaning of the individuals to be reconstructed and for meaning to be rebuilt by symbols. This process of constructing meaning can eliminate violence altogether but it can also be the cause of its existence.

\section{Violence}

Violence comes into being with the existence of humankind and it is a notion that draws the attention of the disciplines of law, health and social sciences and that needs interdisciplinary study [8].

Violence in general is interpreted as "toughness, stringency, trial of force or power" [9] Turkish Language Association refers to violence as "of a movement, a power degree, intensity, hardness, a rising power from the movement, using brute force to those who are opposing views, brute force, feelings and behavior excesses" refers to the form. Addition to this Cambridge dictionary defines "violence"; actions or words that are intended to hurt people, extreme force [10]. Proceeding from these definitions of violence is reached the conclusion that the more undesirable and negative perceived phenomenon. But to make a definition that everyone can accept as conclusive regarding of violence is quite difficult.

In this regard, the concept of violence committed by Hannah Arendt and a description of everyone being able to tell how hard does a quote from Sorel. Sorel says "violence 
problem is still dark". Also this sentence motions by Arendt "this jurisdiction, then it is true that this day as much as it is" [11], saying the violence could compromise on everybody about a definition specifies that it wouldn't be easy to do.

The main subject of violence is the usage of brute force which applied to a person or group [12]. But not only human to human also have human's physical attacks to animal or objects found corresponded with terminology of violence. Final point of the usage of violence is the action of kill and we can describe that as the actual absolute violence [7]. Nowadays, everything is seen as violence that afflicts it with anybody else and therefore according the type of violation can be classified in various ways. In short, the narrow definition of violence is physical violence that draws attention to the physical action of the victims and in the broader category it also covers the economic and psychological forms of violence. With this definition of violence does not cover only the victims of physical damage also covers victims who experienced economic deprivation, spiritual oppression, humiliation and tortured prospects [8]. This shows us so many different types of violence as individual, collective, economic or industrial violence.

Another significant issue is in the case, challenging against to violence with violence causes continuity of violence in the human life. In our era we can find all patterns of the violence and the violence has spread to every corner of our lives. Although the steps which taken response for eliminating violence is causing a new wave of violence. Hannah Arendt's identifications on this issue are very crucial.

Arendt determined that, "the risk of violence (violence, consciously pursuing short-term goals, even if moving in a frame against extremism) is always: Tools get out of purposes. Unless the objective is reached quickly, the result is not only defeat, worse, will be the introduction of violence into the political field. Action cannot be undone and return to the status quo is always the unlikely case of defeat. Each action, as well as the practice of violence transform the world but the most probable transformation will be more violent world line " [11].

As a result, the factors that causes many different types of violence offers a wide variety. Ultimately Violence is a tool to establish dominance over the others and therefore reflections of that will be very different.

\section{ON PHENOMENON OF VIOLENCE GENERATED BY ALIENATION ORIGINATED IN LANGUAGE}

There is no indication of violence that independent from the linguistic and symbolic integrity. It is difficult to present a clear distinction between language and violence which has a major impact on the science of discourse [7]. Despite issues of different areas, the tools of symbolic interaction which is language and violence actually carries always a nested character. While the interpretation processes actually creating the intellectual infrastructure of physical violence, we can easily observe in the human life that is done by using the tool called language. Language is a comprehensive organism that may not only consider as a communication tool just regulates the social relations.

Language is a living entity containing its own violence elements and has consistently productive character. In this sense, the language is dynamic and has a vivacious structure. Language produces thoughts and feelings and sustains its effectiveness by transferring these with speech acts. Thoughts and emotions are also involved in the production of social interaction and socialization process. Violence exists in the language established domination on the individual and society in every era due to adopt itself to language's symbolic order as such violence has always been the tool of power and sovereignty.

Habermas stresses phenomenon of violence which already existed in language, arise with use of language and that is a product the language's action. Violence as a tool of power and sovereignty is also an indicator as well. Attacks of any kind, either physically or speech acts have been exposed to violence for establishing domination [7]. Human begins to perceiving, understanding and disputing the living world with the help of language. Establish and plan its own facts on language and hereby this functional feature of language can be turned into a tool of power and violence.

Usage of language causes violence has active role in the abuse of language. Possibilities and flexibility presented by the language are used maliciously for the profit and motivation. According to this we can give example from the speech of Priest Martin von Pairis which is appointed by Pope after the captured of Jerusalem by Sellahaddin Eyyubi:

"O parish, brothers and sisters let me make a speech -not really for myself, in the name of Jesus: Jesus inspires me personally, I'm just a sacred middleman of him. Jesus will appeal to you today with his own words, he will complain about the injustice done to him, from the Jesus' holy home Jerusalem. He banished from the holy city where he blessed with his own blood. Good Heavens! Where is this place explicated by the prophet, where is this city which the son of God born in a temple as a little child? Who have the city where he and disseminated his teachings, made miracles repeatedly, blessed most sacred one's blood and body while having the last supper with his disciples? Where this city where he suffered, died, buried and reborn after three days is? Now the people in that city pagan barbarism raging! $O$ misery; tears, endless misery! The holy land where Jesus directs the steps in this country he healed the patients, opened the eyes of the blinds, cleaned the wounds of lepers and resurrected the dead. Now this land captured by infidel countries! ... This sacred country's Christian population destroyed by enemy's sword or permanent captivity ... Today, what is asked for you understand the sufferings of Jesus. O you mighty warriors, now come and help him, join the crusade; join wholeheartedly in this army! I rely on you in the Christianity case; I leave it in your hands, make an effort to regain his heritage where he fired cruelly! ... If you ask me what you can wish as reward from God for your effort is, of course I promise for these: everybody who put the sign of the cross on their clothes and atoned for their sins, they will sanctified and reach the eternal life. You see brothers and sisters, how glorious faith for this crusade and with this confidence is certain that for go to heaven and join to crusade within have a hope for living happier life there." [7]

The quote above inviting people to war, explaining his own religious perception as sacred, accepts the other 
religious perceptions as others and through this base speech triggers to the alienation in a conscious manner. Ascribed meanings to the symbols draw sharp lines between the different religions, also alienate people to each other that triggered the violence for destroying out of the other and have a preparative content to a legit ground for violence. In the process of interpretation, language takes position as a tool of separation and break, briefly tool of alienation.

Martin Luther's (pioneer of the reform movement) expressions to the German peasant who rebelled against the German prince are filled with items of alienation that occurs over signification process of the language and violence; these items also give violence a legitimate character.

"Decedents who supported the prince will go to the heaven as sacred religious warriors; the others' spirits will turn into devil. Everyone should strangle, stab and kill that kind of people who stand against prince by using traps or to dare them clearly. And everyone should know that there is no being more toxic, harmful and demonic than a rebel." [13].

It is very important in terms of showing how alienated they are or how marginalized they are in this direction and get a legitimate status as a result of this violence to each member of the same ethnic background as seen in the above line. Luther considers the Germans who do not stand at the same area as elements which will be destroyed and he invites to the violence. This speech and language, as well as a means for building a meaningful world who think like Luther, and Luther do not have the face of factors, is used as the key to alienation and violence. Loaded meaning of language association triggers decomposition.

Again in this manner is filled with Adolf Hitler's book Mein Kampf which accepted as a holy book for the National Socialists causing alienation over meaning and factors that triggered the violence will occur as a result of this:

"If Nature does not wish that weaker individuals should mate with the stronger, she wishes even less that a superior race should intermingle with an inferior one; because in such a case all her efforts, throughout hundreds of thousands of years, to establish an evolutionary higher stage of being, may thus be rendered futile. History furnishes us with innumerable instances that prove this law. It shows, with a startling clarity, that whenever Aryans have mingled their blood with that of an inferior race the result has been the downfall of the people who were the standard-bearers of a higher culture." [14]

"In short, the results of miscegenation are always the following:

(a) The level of the superior race becomes lowered;

(b) Physical and mental degeneration sets in, thus leading slowly but steadily towards a progressive drying up of the vital sap.

The act which brings about such a development is a sin against the will of the Eternal Creator. And as a sin this act will be avenged." [14].

"All the great civilizations of the past became decadent because the originally creative race died out, as a result of contamination of the blood. He who would live must fight. He who does not wish to fight in this world, where permanent struggle is the law of life, has not the right to exist. Whoever ignores or despises the laws of race really deprives himself of the happiness to which he believes he can attain. For he places an obstacle in the victorious path of the superior race and, by so doing, he interferes with a prerequisite condition of all human progress. Loaded with the burden of humanitarian sentiment, he falls back to the level of those who are unable to raise themselves in the scale of being." [14]

"In the German language we have a word which admirably expresses this underlying spirit of all work: It is Pflichterfüllung, which means the service of the common weal before the consideration of one's own interests. The fundamental spirit out of which this kind of activity springs is the contradistinction of 'Egotism' and we call it 'Idealism'. By this we mean to signify the willingness of the individual to make sacrifices for the community and his fellow-men. " [14]

Hitler placing German race separate location than all among others by drawing a sharp border and thus loading negative meaning to races except Aryan race. He builds the interpretation process through the alienation. Firstly he alienates people to each other by sorting the Aryan race's superior qualities which separate from them. When alienation becomes corporate in people's minds and in their hearts, violence gets inevitably legitimate ground. As a result, it begins the process from individual violence to collective violence.

"The Jew offers the most striking contrast to the Aryan. There is probably no other people in the world who have so developed the instinct of self-preservation as the so-called 'chosen' people." [14]

"If the Jews were the only people in the world they would be wallowing in filth and mire and would exploit one another and try to exterminate one another in a bitter struggle, except in so far as their utter lack of the ideal of sacrifice, which shows itself in their cowardly spirit, would prevent this struggle from developing. " [14]

"In order to form a correct judgment of the place which the Jew holds in relation to the whole problem of human civilization, we must bear in mind the essential fact that there never has been any Jewish art and consequently that nothing of this kind exists today. We must realize that especially in those two royal domains of art, namely architecture and music, the Jew has done no original creative work. When the Jew comes to producing something in the field of art he merely bowdlerizes something already in existence or simply steals the intellectual word, of others." [14].

"The life which the Jew lives as a parasite thriving on the substance of other nations and States has resulted in developing that specific character which Schopenhauer once described when he spoke of the Jew as 'The Great Master of Lies'. The kind of existence which he leads forces the Jew to the systematic use of falsehood, just as naturally as the inhabitants of northern climates are forced to wear warm clothes." [14]

"He is obliged to conceal his own particular character and mode of life that he may be allowed to continue his existence as a parasite among the nations. The greater the intelligence of the individual Jew, the better will he succeed in deceiving others." [14] 
In summary, Hitler brings out the history of the Jews from the defeat of First World War due to analyze the destruction of the others. He says "At the beginning of the War, or even during the War, if twelve or fifteen thousand of these Jews who were corrupting the nation had been forced to submit to poison-gas, just as hundreds of thousands of our best German workers from every social stratum and from every trade and calling had to face it in the field, then the millions of sacrifices made at the front would not have been in vain. On the contrary: If twelve thousand of these malefactors had been eliminated in proper time probably the lives of a million decent men, who would be of value to Germany in the future, might have been saved." [14]. Alienation through individuals begin to define the other to the other in his mental world, the content of the meaning attributed to the other also perceived as an element that threatens its survival (with quite a negative figure), this also makes it inevitable to undergo other violence. Violence has found a legitimate ground and the other will be ignored physical destruction for the sake of a good purpose. Interpretation will be re-established itself in this direction.

Zygmunt Bauman claims that all modern states could fit the same pattern, except the small distinctions between them in his book which called Modernity and the Holocaust and the pattern set by the bureaucracy and the division of labor. Bauman, also underlines Nazi Germany organized like other modern states and declares that the Holocaust one of the possible corollary of this pattern [15]. Although these findings of Bauman are quite original to destroy the others individuals need to justify the massacre in question and meaningful arguments. In fact, the organization of the modern state and the individual's work or what it does serve as a kind of perception of the world where the individual is a result of signification by this direction. This signification process has opened the door of alienation and the multi-dimensional violence process continued until the concentration camps and Holocaust.

A similar example we can show from fatwa issued in 1998 by the leaders of the terrorist organization al-Qaeda, Ayman al-Zawahiri and Osama Bin Laden. According to this fatwa; "To fight against the Americans and kill them, regardless civil or military" [16] is described as the duty of every Muslim. Interpretation is a category that has alienated the other while they are building on absolutes their own religion. After this point, violence has a legitimate dimension for alienated individual. As a current example, spokesman of the terrorist organization called the Islamic State (claiming they had established state Iraq and Syria) Abu Muhammad al Adnann's speech may also be shown:

$O$ America, $O$ allies of America, and $O$ crusaders, know that the matter is more dangerous than you have imagined and greater than you have envisioned. We have warned you that today we are in a new era; an era where the State, its soldiers, and its sons are leaders not slaves. They are a people who through the ages have not known defeat. The outcome of their battles is concluded before they begin." "And so we promise you by Allah's permission that this campaign will be your final campaign. It will be broken and defeated, just as all your previous campaigns were broken and defeated, except that this time we will raid you thereafter, and you will never raid us. We will conquer your Rome, break your crosses, and enslave your women, by the permission of Allah, the Exalted."

"So mobilize your forces, O crusaders. Mobilize your forces, roar with thunder, threaten whom you want, plot, arm your troops, prepare yourselves, strike, kill, and destroy us....Send arms and equipment to your agents and dogs. Prepare them with the most modern equipment. ... Look at your armored vehicles, machinery, weaponry, and equipment. It is in our hands. ... and O Obama, O mule of the Jews. You are vile. ... Have you not realized $O$ mule of the Jews, that the battle cannot be decided from the air at all? Or do you think that you are smarter than Bush, your obeyed fool, when he brought the armies of the cross and placed them under the fire of the mujahidin on the ground? No, you are more foolish than him. ... You claimed to have withdrawn from Iraq -O Obama-four years ago. We said to you then that you were liars, that you had not withdrawn, and that if you had withdrawn that you would return, even if after some time, you would return. Here you are; you have not withdrawn. Rather you hid some of your forces behind your proxies and withdrew the rest. Your forces will return greater in number than they were before. You will return and your proxies will not avail you. And if you are not able to return, then we will come to your homeland by Allah's permission."

"O mujahidin in Khorasan, the Caucasus, and Iran... O mujahidin everywhere upon the face of the earth... O brothers in creed... O you who have loved the Islamic State... O you who support the Caliphate... O you who consider yourselves from amongst its soldiers and patrons... Your state is facing a new campaign by the crusaders. So $O$ mujahidin, wherever you may be, what are you going to do to support your brothers? What do you wait for as the people have become two encampments and the heat of the war increases day by day? O mujahidin, we call you up to defend the Islamic State."

"Finally, we do not want to forget to direct a message towards our Muslim people and brothers from the Kurds in Iraq, Sham, and elsewhere. Our war with Kurds is a religious war. It is not a nationalistic war-we seek the refuge of Allah. We do not fight Kurds because they are Kurds. Rather we fight the disbelievers amongst them, the allies of the crusaders and Jews in their war against the Muslims. As for the Muslim Kurds, then they are our people and brothers wherever they may be. We spill our blood to save their blood. The Muslim Kurds in the ranks of the Islamic State are many. They are the toughest of fighters against the disbelievers amongst their people." [17].

A similar case in this description that is the meaning process of language triggers for both alienation and unity. He portrayed their struggle when facing those who are in a holy and divine dimensions, such as an object, are totally alien character outside of this purpose. The elimination of foreign naturally is for the sake of a holy purpose. Interpretation generates alienation, alienation generates violence. This is one of the reasons behind the brutal images that we see frequently in these days as cutting off people's heads. They consider stranger as an element that should be eliminated 
because he is outside their own world of meaning. The sense of purpose in the form of a sacred heart and mind of the individuals applied to the other due to founding a legitimate ground and justify violence has become a routine for the individual actions.

\section{CONCLUSION}

Today's world is supporting the alienation that occurs through the process of signification which is concerned. This phenomenon has to be one of the largest problematic to bring the violence in today's world. Today, the reigning world while building his own world through their sense the concept of violence against his own for the removal of the other, in this case, violence is used as an important the tool by both define and defined.

Violent images which we get used to see rather frequently through the mass media actually have the same feeling at the background. Violence has also been moved to a global dimension in the globalizing world. In a time when people alienated to people, violence is the most likely tool of sovereignty. The meaning is very important in this process. The world's dominant power uses the same arguments to destroy the threat to the era in question lived with meaning. While the civilized world, threatening and using violence as a means of interpretation as other elements as a means of eliminating the other is used violence again. The other refers to applying similar methods of violence to another. Defining their meaning through the other world, because this definition results in the other a stranger to his other violence by claiming that makes for a sacred purpose. This shows us the violence phenomenon and alienation revealed by the interpretation process has a direct relationship. The main element of symbolism, which is used by people to give meaning to their lives and language assumed a character that generates both alienation and violence. It does not result in symbolism and interpretation to the language which is the most powerful tool not only the violence but also plays the role earned him a legitimate character. Person alienates himself and his environment by the interpretation process over the world that is also causes the new wave of violence.

\section{REFERENCES}

[1] S. Özbudun, G. Markus, and T. Demirer, "Yabancılaşma," Ütopya Yayınevi, Ankara, pp.16-20, 2007.

[2] K. Marx, "Yabancılaşma," Sol Yayınlarl, Ankara, pp. 9-93, 2013.

[3] M. Ertoy, "Yabancılaşma kader mi, tercih mi?" Lotus Yayınevi, Ankara, p. 56, 2007.

[4] S. Teber, "İnsanın hiçleşme serü venine giriş," Papirüs Yayınları, İstanbul, p. 141, 2001.

[5] T. Bottomore and R. Nispet, "Sosyolojik çözümlemenin tarihi," Kirmızı Yayınlarl, İstanbul, pp. 501-546, 2010.

[6] A. R. Wallace and A. Wolf, "Çağdaş sosyoloji kuramlari-klasik geleneğin genişletilmesi," Doğu Batı Yayınları, Ankara, 2013, pp. 291-294.

[7] İ. Karabağ, "Dil ve şiddet-geçmişten günümüze bir kavram incelemesi," Íkaros Yayınları, İstanbul, pp. 10-60, 2010.

[8] İ. User, B. Kümbetoğlu, and T. Kolankaya, "Şiddete ilişskin bir bilinç Yükseltme çalişmasi," Yoksulluk, Şiddet ve İnsan Haklarl, TODAİE, Ankara, p. 158, 2002.

[9] D. M. Doğan, "Büyük Türkçe sözlük,” Rehber Yayınevi, Ankara, p. 1038, 1990.
[10] Cambridge Dictionaries Online. [Online]. Available: http://dictionary.cambridge.org/

[11] H. Arendt, "Şiddet üzerine," İletişim Yayınları, İstanbul, pp. 45, 2012.

[12] E. Acar, "Aile ve çocuk eğitiminde şiddet siz siniz," Yediveren Yayınları, İstanbul, p. 13, 2012.

[13] S. Zweig, "Roterdamlı erasmus: zaferi ve trajedisi," Can Yayınlarl, İstanbul, p. 167, 1997.

[14] A. Hitler, "Kavgam," Toker Yayınlari, Ankara, pp. 319-320, 2001.

[15] T. Aygün, "Efendiliğin reddi - sivil itaatsizlik ve doğrudan eylem," Versus Kitap, İstanbul, pp. 272-273, 2006.

[16] E. Demirel, "Türkiye'de el-kaide unsurlari," IQ Yayınları, Ístanbul, p. 20, 2005.

[17] Tevhidigundem. [Online]. Available: http://www.tevhidigundem.com/seyh-adnaniden-gundeme-dair-acikla malar-1921h.htm

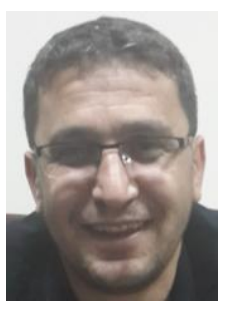

Selçuk Aydın was born in Erzurum, Turkey in 1978 He studied tourism management in Uludağ University from 1996 to 1998. After that he has received his B.A from Atatürk University about sociology in Erzurum, Turkey from 1999 to 2003 and he obtained his M.A degree in 2005 about in philosophy at Atatürk University in Erzurum. Finally, he took his Ph.D in sociology in 2011, Erzurum. He is still holding position of assistant professor in Political and Social Sciences Department at Kafkas University. His major interests are in political sociology and political philosophy.

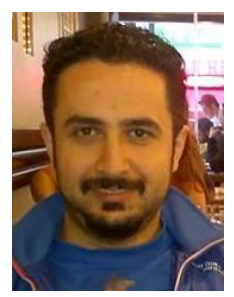

Atıl Cem Çiçek was born in Kars, Turkey in 1982. He has received the B.A. in public administration from Akdeniz University. He received M.A. in the public administration and the $\mathrm{PhD}$ in the same field from İnönü University. He is holding position as assistant professor in Political and Social Sciences Department at Kafkas University in Kars, Turkey. His major interests are political thought and Turkish political life. He has published an article about ideology, space and politics in Rome and published a book about public administration.

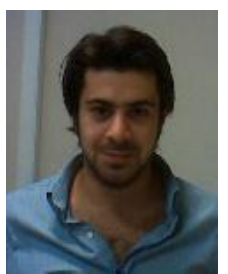

Melih Çağatay Artunay was born in İstanbul, Turkey in 1986. He studied political sciences and international relations at University of Bahçeşehir in Istanbul. He has earned his M.A degree from political sciences in 2011 from Galatasaray University. Currently, he is doing his Ph.D at the Istanbul University in political science. He is still working as research assistant in political and social sciences at Department at Kafkas University. His major interests areas are international relations, political sociology and political thought. He published an article that "An Essay on the Relation between Ideology and Architecture: Case of Turkey" at Academic Journal of Interdisciplinary Studies, Rome in 2013.

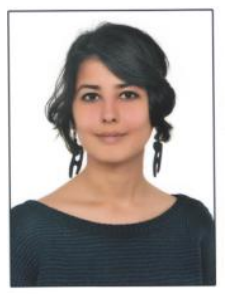

Aliye Bilge Certel was born in 1990 at Burdur, Turkey. She has received the B.A. in Public Administration Department of Akdeniz University, Antalya. She is still studying in the same field at the same University as master student. She working as a research assistant in Political and Social Sciences Department at Kafkas University in Kars, Turkey. Her major interests are political thought, philosophy and political sociology. 